OPEN ACCESS

Edited by:

Marybeth Gasman,

University of Pennsylvania,

United States

Reviewed by:

Andrew Martinez,

University of Pennsylvania,

United States

Andrés Castro Samayoa,

Boston College, United States

*Correspondence:

Rose Ann E. Gutierrez

raegutierrez@ucla.edu

Specialty section:

This article was submitted to

Leadership in Education,

a section of the journal

Frontiers in Education

Received: 01 June 2018

Accepted: 09 August 2018

Published: 04 September 2018

Citation:

Gutierrez RAE and Le A (2018)

(Re)conceptualizing Protests:

Activism, Resistance, and AANAPISIs.

Front. Educ. 3:70.

doi: 10.3389/feduc.2018.00070

\section{(Re)conceptualizing Protests: Activism, Resistance, and AANAPISIs}

\author{
Rose Ann E. Gutierrez* and Annie Le \\ Department of Education, University of California, Los Angeles, Los Angeles, CA, United States
}

Though protests on college campuses have captured public attention, far less consideration has been paid to Asian American Native American Pacific Islander Serving Institutions (AANAPISIs). The Asian and Pacific Islander American (APIA) population has historically served on the front lines of the Asian American Movement during the Civil Rights Movement influencing the educational experiences of APIA students. While literature documents student activism from APIA students, they are portrayed as an apolitical group. The purpose of this article is to (re)conceptualize the term protest to capture the historical and contemporary forms of activism by researchers, policy makers, community organizers, and students throughout a decade that pushed a legislation forward to create the federal designation for AANAPISIs. We argue that the term protest is limiting in research. Instead, the term activism should be used in order to encapsulate the ways APIAs have been engaged socially and politically. Additionally, there exists a gap in educational literature discussing how the spatial politics of domination and resistance manifests in representational spaces - in this case institutional structures like AANAPISIs. Influenced by spatial politics and spatial theory we put forth a conceptual argument that the representational existence of AANAPISIs is a site of resistance that needs to be better understood, especially in the era of Trump where anti-immigration and racist rhetoric is ever-present, because of the ways APIAs continue to be racialized and (re)positioned in United States racial discourse and research.

Keywords: AANAPISI, resistance, activism, race, minority serving institution

\section{BEYOND PROTESTS}

Though protests on college campuses have captured public attention, far less consideration has been paid to Asian American Native American Pacific Islander Serving Institutions (AANAPISIs), which enroll at least 10 percent of Asian American and Native American Pacific Islander students. We recognize a plethora of acronyms is used to describe Asian American, Native Hawaiian, and Pacific Islander communities. We use the term Asian and Pacific Islander American (APIA) intentionally to convey that Pacific Islanders can be Americans too. The APIA population have historically served on the front lines of the Asian American Movement during the Civil Rights Movement influencing the educational experiences of APIA students (Umemoto, 1989; Nguyen and Gasman, 2015). While literature documents student activism from APIA students (Umemoto, 1989; Wei, 1993; Teranishi, 2007; Park et al., 2008; Ryoo and Ho, 2013; Nguyen and Gasman, 2015; Kodama et al., 2017; Manzano et al., 2017; Wray-Lake et al., 2017), they are portrayed as an apolitical group. For example, 
the University of California, Los Angeles (UCLA) Freshman Survey reported that only six percent of APIA students are likely to protest in college (Eagan et al., 2015).

We argue that the term protest is limiting in research. Instead, the term activism should be used in order to encapsulate the ways APIAs have been engaged socially and politically. The way research defines and collects data does not fully capture the experiences of APIA students at AANAPISIs. For example, historically, APIA students have protested at large, public institutions like the University of California, Berkeley and University of California, Los Angeles (Nguyen and Gasman, 2015), yet these 4-year institutions are not designated as AANAPISIs. In addition to meeting an enrollment threshold of at least 10 percent undergraduate APIA students, at least 50 percent of the institution must also have its students receiving financial assistance through programs like the Federal Pell Grant, Federal Supplemental Educational Opportunity Grant, Federal Work Study, or the Federal Perkins Loan. Although some institutions have a high undergraduate enrollment of APIA students, they do not meet the latter requirement to be federally designated as an AANAPISI. Additionally, methodological instruments like the Cooperative Institutional Research Program (CIRP) at the UCLA's Higher Education Research Institute only surveys 4year institutions, explicitly including Historically Black Colleges and Universities (HBCUs) in their report of student protests. In CIRP's 2015 report, The American Freshman: National Norms Fall 2015 (Eagan et al., 2015), two questions ask firstyear students about protests. Question 34 asks how frequently students engaged in a "[demonstration] for a cause (e.g., boycott, rally, protest)" (p. 70). Question 51 asks the students' "best guess as to the chance that [they] will participate in student protests or demonstrations" (p. 72). Moreover, these questions asked in the Freshman Survey are not asked with followups in the College Senior Survey administered by CIRP. The survey also narrowly defines protests and demonstrations on campus. This leaves 2-year institutions out, which make up over half of AANAPISI institutions (CARE, 2012), and further renders invisible protests that could be occurring on these campuses.

Thus, the purpose of this article is to (re)conceptualize the term protest to capture the historical and contemporary forms of activism by researchers, policy makers, community organizers, and students throughout a decade that pushed a legislation forward to create the federal designation for AANAPISIs. Beyond protests, we name this activism the transformative triad that brought about the emergence of AANAPISIs. Additionally, there exists a gap in educational literature discussing how the spatial politics of domination and resistance manifests in representational spaces-in this case institutional structures like AANAPISIs. Influenced by feminist spatial politics (Beebe et al., 2012) and spatial theory (Lefebvre, 1991), we put forth a conceptual argument that the representational existence of AANAPISIs is a site of resistance that needs to be better understood, especially in the era of Trump where antiimmigration and racist rhetoric is ever-present, because of the ways APIAs continue to be racialized and (re)positioned in United States racial discourse and research.

\section{THEORETICAL FRAMEWORK: PLACE, SPACE, AND RACE}

Minority Serving Institutions (MSIs) are the physical manifestations where forms of inequity intersect, yet these institutions actively mitigate social stratification through equitable, culturally conscious policies and practices (Nguyen et al., 2018). Moreover, AANAPISIs are the actualized space of resistance, symbolically and pragmatically (Park and Chang, 2010). We use the term space as opposed to place to signify its conceptual and material meanings instead of its geographical location. Cresswell (2004) suggests that place "is not simply an outcome of social processes.... it was, once established, a tool in the creation, maintenance and transformation of relations of domination, oppression and exploitation" (p. 20). Feminist spatial politics (Beebe et al., 2012) and Lefebvre's (1991) influential book on the spatial turn, The Production of Space, has informed our conceptualization of AANAPISIs as a space of resistance during the era of Trump. Moreover, we will refer to AANAPISIs as sites of resistance. The spatial turn describes a time in the early 1990s when cultural theorists and geographers began thinking about and understanding space beyond its preconceived static form (Beebe et al., 2012). Rather, space is dynamic where areas of struggle overlap and intersect shaping beliefs, ideas, and values. Spaces of resistance can birth agency.

Feminist history of problematizing the politics of space and place in relation to gender grounds our conceptual argument in the spatial politics of space. Beebe et al. (2012) analyze gendered meanings of spaces in connection to society's understanding of power dynamics between women and men. Specifically, Linda McDowell elaborates "gender identities [being] a key part of the establishment and maintenance of women's position" (as cited in Beebe et al., 2012, p. 524). Historically, discussions of gendered spaces (i.e., home and work) were viewed through a binary lens that have stifled researchers' abilities to conceive gender stratification beyond the binary. Spaces excavate issues of race, class, sexuality, and gender by bringing them to surface through a contested physical arena. While feminist scholarship explores the spatial politics of space in relation to gender (Beebe et al., 2012), race is at the epicenter of this article. Similar to the limitations of thinking about gender through a binary, Black and White paradigms of conceptualizing race cripple imaginaries in considering students who do not fit preconceived definitions of "underserved" or "marginalized." The federal legislation and designation of AANAPISIs disrupt the Black and White binary and insert APIA students in racial discourse and policies. AANAPISIs are tangible spacespolitical spaces of race-representing the unique needs of APIA students, who have been historically and continue to be misrepresented, misunderstood, and misinterpreted in educational research.

Lefebvre (1991) discusses three aspects of space that contributes to a larger understanding of the production of social space: spatial practice, representations of space, and representational spaces. Spatial practice refers to perceptions of space and how it is practiced in everyday life. Representations 
of space refers to conceptions of space and the signs, codes, symbols, and meanings attached to these representations. Representational space refers to the "product of a relationship between spatial practice and representations of space" (p. 39). Thus, representational space is the lived space which exists within our physical reality. In relation to AANAPISIs, the activism by researchers, policy makers, community organizers, and students to push for its federal designation as an MSI carved out a representation of space in society's mind that was being misconceived and misrepresented by the model minority stereotype. This representation of space by a legislation signaled that APIA students do have academic needs, thereby actively challenging the model minority myth, a distorted image of a racial group surpassing achievements of others. Although the introduction of a legislation happened in 2002, Espiritu (1992) notes that Congressmen Robert Matsui (D-CA) and Norman Mineta (D-CA) objected the exclusion of APIA students from minority student counts regarding MSI status as early as 1986. A representational space of an institution with the purpose of providing support specifically to a racial group transforms that abstract thought to reality. A concrete space, such as an educational institution with aims to serve a particular racial group, has ramifications for our understanding and perceptions of race and its intersection with class in the United States. Spaces are political, and the ways in which AANAPISIs was conceived and its continued existence is racially political.

\section{TRANSFORMATIVE TRIAD: TRIPARTITE NEXUS OF RESEARCH, POLICY, AND PRACTICE}

While student protests have been rendered invisible at AANAPISIs, recognizing the emergence of this particular MSI from years of activism through collaboration between policy makers, researchers, community organizers, and students is critical in understanding the sociohistorical significance of AANAPISIs within the larger MSI discourse. AANAPISIs do not have a legacy of protests, similar to that of HBCUs and Tribal Colleges and Universities (TCUs), because only a decade has passed since its federal designation. The legislation that brought about the creation of AANAPISIs embodies the ideal tripartite nexus of research, policy, and practice to bring about political and social change through activism. The word "activism" dates as early as 1907 in philosophical theory. The term is often associated in a political sense, and society has come to understand it as an energetic set of actions to achieve social change. We (re)conceptualize the term protest to capture the years of persistent advocacy through a collaborative of researchers, policy makers, community organizers, and students to push a legislation that recognized and carved an institutional site to serve the unique needs of APIA students. Furthermore, we call this activism the transformative triad of research, policy, and practice that goes beyond its interplay, but rather works in complementary gears mutually strengthening and informing its parts and players to create change. AANAPISIs serve as evidence that out of the transformative triad, which can only be achieved when each component builds upon one another to move forward, comes the possibility of social change.

Park and Chang's (2010) article grounds the transformative triad into concrete examples of how AANAPISIs were created, particularly with politically significant events that led up to its designation. One can argue that the inception of this legislation started with the community. It was community leaders after all who expressed their frustration in political forums with the ways in which their challenges as APIAs are obscured through misleading data, such as that in Reaching the Top: A Report of the National Task Force on Minority High Achievement, a report published by the College Board in 1999. Not only did this report collapse Asian American with White students, they only included East Asian students in the sample. The report concluded that Asian Americans did not face educational barriers, aligned with the model minority myth. They voiced concern that their academic needs are not taken seriously and remain low priority in policy. The advocacy efforts of community leaders eventually led to the creation of the White House Initiative on Asian Americans and Pacific Islanders in 1999 and to a report that recommended a federal designation for institutions that served a sizeable APIA population in 2001. Consequently, H.R. 4825 was introduced the following year that would extend MSIs to include institutions that enroll at least 10 percent of APIA students. Naturally, this policy was backed by the community. For example, the National Asian American Student Conference (NAASCon) provided grassroots support from students to pass the legislation. Research, however, was needed to move this bill forward.

The head of the Education and Labor Committee, Howard McKeon (R-CA), was willing to help with the legislation if research from the Government Accountability Office (GAO) corroborated the unique academic needs of APIA students. The primary sponsor of the bill, David Wu (D-OR), requested for the report to be conducted from GAO. Nearly two years later, the findings of the report were consistent with other research on disaggregated APIA data: Southeast Asians and Pacific Islander students had drastically low educational attainment as well as socioeconomic status. Additionally, the support for an institution to serve APIA students was implied in the report. Though practice and research was necessary to advance the bill, policy also played an important role in the passing of this legislation. Auspiciously, several months after the GAO report, the Democrats made up the majority of the House of Representatives and Senate. Park and Chang (2010) caution that there was a chance the bill would not have passed under Democratic control, but the change provided a unique opportunity for the AANAPISI designation.

Together, each component (i.e., research, policy, and practice) of the transformative triad made possible what seemed insensible as a result of the model minority myth-a designated space in which APIA students would be supported in higher education. Activism was necessary and required for AANAPISIs to take shape. The racial positions of APIAs meant that they had to 
be more strategic in their advocacy, as traditional forms of activism such as protests would render them invisible because they were not "marginalized enough." Instead the AANAPISI designation had to take place in the context of existing MSIs in which APIAs had to prove, through research, their minority status. The AANAPISI designation illustrates not only the difficulty for APIAs to be included in a racial discourse, but that their activism had to look different from other racial groups in order to be legitimate. Though the process of obtaining AANAPISI designation was not necessarily resistance since it went through proper political channels, present day AANAPISIs are actually sites of resistance as the prevalence of the model minority myth still dominates narratives of APIAs today.

\section{TRANSFORMATIVE TRIAD BIRTHS AANAPISI AS A SITE OF RESISTANCE}

Lefebvre (1991) imparts an understanding on the production of social space, and Beebe et al. (2012) elucidate the reproduction of power and hierarchies through the construction of social spaces. Additionally, Lefebvre's (1991) theoretical framework on the social production of space makes lucid the politics of domination and resistance that is exhibited in representational space or lived space. Adapting Lefebvre's (1991) spatial triad, we argue that AANAPISIs, then, are representational spaces of resistance, especially in the era of Trump. Since he took office, 16 staff members from the White House Initiative on Asian American and Pacific Islanders have resigned, leaving only five staff left (Lee, 2017). Under the new political climate, APIAs are vulnerable to racial (re)positionings through policies and practices without members from the President's Advisory Commission to represent the APIA community. One member stated his reason for resignation is because “Trump administration's activities ... have threatened the progress made by former President Barack Obama for AAPI communities" while their collective resignation letter cited the "president's 'portrayal of immigrants, refugees, people of color and people of various faiths as untrustworthy, threatening, and a drain on our nation"' as an explanation for their departure (Lee, 2017). Additionally, despite data that shows the positive impact of federally funded AANAPISI programs, there continues to be a lack of financial support for these institutions (Gasman and Nguyen, 2014). The White House budget for higher education demonstrated that there will be a zero percent budget change for AANAPISIs (Kreighbaum, 2017) even though the enrollment rate for APIA students have been increasing (CARE, 2014, 2015). The lack of representation for the APIA community under this administration can lead to negative symbolic and pragmatic consequences for both AANAPISIs and APIA students.

While APIAs are generally excluded from racial discourse, they are also mentioned without consent to serve the interests of racially charged social and political agendas. Park and Teranishi (2008) examine the creation of AANAPISIs as a racial project because the federal designation "presents a unique representation of the ongoing evolution of Asian
American racial positioning within American society" (p. 111-112). Therefore, within this racial project, we argue that AANAPISIs are sites of resistance symbolically and pragmatically, specifically in the spatial politics of race. As sites of resistance, AANAPISIs are symbols that resist dominant narratives by unraveling ideologies embedded in educational institutions. Thus, pragmatically reinforcing the necessity for researchers, policy makers, community organizers, and students to decipher how inequity is reproduced and reduced. AANAPISIs provide a representation of space through a representational space that challenges the model minority myth and (re)positions APIA students in the racial fabric of the United States in alignment with historically marginalized racial groups. AANAPISIs compel the APIA community to control their narrative. Moreover, this institutional structure has the potential to uncover limitations and possibilities further aiding the development of APIA students' critical consciousness. Meaningful information, social support, and involvement in organizations and political action contribute to this critical consciousness (Osajima, 2007), which can bring about various forms of activism on- and off-campus.

Resistance has often been associated to individuals and groups of people, but not necessarily institutions and other spaces. Expanding upon our conception of activism and resistance is important to capture the distinct efforts of particular groups to challenge the status quo and combat social inequity. AANAPISIs are sites of resistance for symbolic and pragmatic reasons. Symbolically, AANAPISIs challenge the model minority myth (Laanan and Starobin, 2004; Park and Teranishi, 2008; Park and Chang, 2010). Given their designation as a minority serving institution, it legitimizes and proves that APIA students are minorities and have needs similar to other historically marginalized racial groups in higher education. Pragmatically, AANAPISIs' federal designation paved way for APIA students to be included in policies to receive funding, academic support, and student services (Park and Chang, 2010). Their federal designation constructed an actualized space of resistance, where APIAs are (re)positioned within educational discourse and broadly, the United States racial landscape (Park and Teranishi, 2008). Explicitly connecting spatial discourse to race and critically analyzing where forms of power and resistance manifests in representational spaces is important, especially in the era of Trump because the APIA community needs to take the wheel in controlling their narrative.

\section{MINORITY SERVING}

In order to better understand activism in relation to AANAPISIs, it is important to consider their history, especially as it relates to other MSIs. Our intention is not to compare the institutions based on their differences. Rather, we believe MSIs are not meant to be uniform in their history and structure because the student populations they serve are different. Understanding the differences allows us to appreciate how varying histories of MSIs inform the way activism at each type of institution is unique due 
to the racialization of the population they serve. To think that the long history of APIA activism has any relationship with activism at AANAPISIs would be parochial. HBCUs and TCUs were created by their respective communities due to their historical systemic and legal exclusion of educational opportunities (Gasman et al., 2015). On the contrary, AANAPISIs, like Hispanic Serving Institutions, Alaskan Native and Hawaiian Serving Institutions, Predominantly Black Institutions, and Native American Serving Nontribal Institutions, emerged from demographic shifts as a result of (im)migration. According to Pew Research Center the United States Asian population grew 72 percent (from 11.9 million to 20.4 million) between 2000 and 2015, making them the fastest growing racial group (López et al., 2017).

While APIAs are largely thought of as students at elite institutions, Teranishi (2010) reports 47 percent of APIA students attend community colleges, which make up the majority of AANAPISIs (CARE, 2013). Due to an increasing enrollment of APIA students at 4-year institutions, historically White institutions are also becoming eligible to receive designation as an AANAPISI. Both these institutions, however, still need to gain a better understanding of how to appropriately support and serve the unique needs of a heterogeneous population such as APIA students. Unlike HBCUs and TCUs, AANAPISIs receive designation by their enrollment threshold of APIA students due to demographic shifts. In other words, these institutions were not originally constructed with the intention to serve a specific racial population. This has implications for their access to support services as well as campus climate. Research on the negative experiences of APIA students on college campuses have been well documented (Teranishi, 2010; Wei et al., 2013; Johnston and Yeung, 2014; Museus, 2014; Museus and Park, 2015; Nguyen et al., 2016). Not surprisingly, the way society discusses race through a Black and White paradigm has led researchers to collectively gather, utilize, and advocate for disaggregated data for APIA students. Outside of academia the practice of disaggregated data was still novice. The Reaching the Top report served as a catalyst for APIA policy makers to address the lack of recognition of APIA issues in higher education. The veneer of challenges that APIAs face, especially for certain subgroups, lead APIAs to be consistently misrepresented and misunderstood, especially in education research and discourse (Museus et al., 2013).

In the era of Trump, where alternative facts and fake news are becoming ubiquitous, controlling one's racial narrative is critical. Omi and Winant (2015) posit that the definition of race is insignificant, and the significance of race lies in its external manifestations of lived realities as a category. Because race is a social construct, we have the collective and individual power to transform its meaning (Omi and Winant, 2015). Park and Teranishi (2008) reflect on Takagi's (1992) analysis on the positions of Asian Americans in education as being a "wild card" with an "inconsistent racial status" (p. 11). For example, aggregated APIA data demonstrates their proximity to the academic success of Whites, yet disaggregated data on APIAs reveal their similarities to systemic disparities that align them to American Indian, Black, Indigenous, and Latinx populations. Wu
(2002) further untangles the complexity of the racialization of Asian Americans in his book Yellow by stating:

\begin{abstract}
Asian Americans have been excluded by the very terms used to conceptualize race. People speak of 'American' as if it means 'white' and 'minority' as if it means 'black.' In that semantic formula, Asian Americans, neither black nor white, consequently are neither American nor minority (p. 20).
\end{abstract}

Moreover, Pacific Islanders are grouped with Asian Americans for the purpose of political representation (Park and Teranishi, 2008). In this instance, aggregation and panethnicity is not entirely negative and can serve as political tools for coalition building and advocacy (Museus et al., 2012; Museus, 2014). The term "Asian American" emerged from the 1960s when Chinese, Filipino, and Japanese activists banded together to strategically form a collective identity to fight for their rights during the Civil Rights Movement (Lee, 2015). Aggregation, however, becomes divisive when co-opted and misused to justify a racist ideology and mask systemic racism. For example, aggregating data on APIAs, without the acknowledgment and explanation of nuances, leads to society's misconception of the model minority stereotype. While seemingly "positive" - who would not want to be a model? - this stereotype misinterprets the experiences of the APIA population, excludes them from opportunities through policies and practices, and most importantly, pits them against other Communities of Color to maintain the status quo and a racially stratified society.

Dissenting acts challenging current political and social issues are occurring at AANAPISIs. Research shows how policies and practices in higher education and philanthropic organizations have historically excluded and rendered invisible APIA student experiences through insidious racist ideologies embedded in the model minority stereotype (Osajima, 1995; Suzuki, 2002; Museus, 2009, 2014; Museus and Kiang, 2009; Teranishi, 2010) that continue to plague society's mind. For example, APIA students are typically excluded from funding opportunities that target racial minorities. Doan (2006) writes about programs, specifically the Ford Foundation at first, not considering APIA applicants. Similarly, Park and Chang (2010) mentions how the Gates Millennium Scholars Program initially did not list APIA students as qualified applicants. They argue that ramifications extend beyond educational contexts. Their article reveals that MSIs have the ability to partner with community-based organizations through the Department of Housing and Urban Development to improve surrounding neighborhoods. This also includes outreach programs to children in those communities. Consider the pragmatic or material consequences for APIA students and communities had the model minority myth gone unchallenged. A recent report by CARE (2015) shows APIA students who attend community college demonstrate great financial need. The median income for the report sample was below national poverty level at roughly $\$ 20,000$. The exclusion of an entire racial group from programs that offer financial assistance is at best questionable and at worst oppressive. AANAPISIs, however, carve a representational space for APIA students in the physical 
reality where an educational institution can actively resist exclusionary racial policies and practices through its existence.

\section{IMPLICATIONS}

Collecting, analyzing, and reporting data on APIA students requires intentionality. Efforts from the National Commission on Asian American and Pacific Islander Research in Education at UCLA and the Center for Minority Serving Institutions at the University of Pennsylvania commit to a critical analysis on APIA and AANAPISI data along with advocacy from the Asian Pacific Islander Association of Colleges and Universities (Teranishi et al., 2018). Their efforts offer an accurate portrayal of APIA student experiences that challenge monolithic representations. Moreover, AANAPISIs have the potential to leverage their institutional status and funding to enact policies and programs that can in turn lead to better student outcomes. Studies demonstrate that when AANAPISIs are provided sufficient financial support, they can serve the needs of APIA students (CARE, 2011, 2013, 2014; Teranishi et al., 2012; Nguyen et al., 2014, 2018).

Given the complex, heterogeneous composition of the APIA population, research on AANAPISIs can elucidate a more nuanced understanding of this student population's culture, historical (im)migration patterns, and identity to provide

\section{REFERENCES}

Beebe, K., Davis, A., and Gleadle, K. (2012). Introduction: space, place and gendered identities: feminist history and the spatial turn. Womens His. Rev. 21, 523-532. doi: 10.1080/09612025.2012.658172

Cresswell, T. (2004). Place: A Short Introduction. Malden, MA: Blackwell Publishing.

Doan, K. (2006). A sociocultural perspective on at-risk Asian American students. Teach. Edu. Spec. Edu. 29, 157-167. doi: 10.1177/0888406406029 00302

Eagan, K., Stolzenberg, E. B., Bates, A. K., Aragon, M. C., Suchard, M. R., and Rios-Aguilar, C. (2015). The American Freshman: National Norms Fall 2015. Los Angeles, CA: Higher Education Research Institute, UCLA.

Espiritu, Y. L. (1992). Asian American Panethnicity: Bridging Institutions and Identities. Philadelphia, PA: Temple University Press.

Gasman, M., and Nguyen, T H. (2014). New Report Arms Minority Serving Institutions with Relevancy-Focused Data. Huffington Post. Available online at https://www.huffingtonpost.com/marybeth-gasman/new-report-minorityserving-institutions_b_5156449.html

Gasman, M., Nguyen, T. H., and Conrad, C. F. (2015). Lives intertwined: a primer on the history and emergence of minority serving institutions. J. Divers. Higher Educ. 8, 120-138. doi: 10.1037/a0038386

Johnston, M. P., and Yeung, F. P. (2014). Asian Americans and campus climate: investigating group differences around a racial incident. J. Stud. Affairs Res. Pract. 51, 143-156. doi: 10.1515/jsarp2014-0015

Kodama, C. M., Poon, O. A., Manzano, L. J., and Sihite, E. U. (2017). Geographic constructions of race: the midwest Asian American students union. J. Coll. Stud. Dev. 58, 872-890. doi: 10.1353/csd.2017.0069

Kreighbaum, A. (2017). Trump Budget would Slash Student Aid and Research. Inside Higher Education. Available online at https://www.insidehighered.com/ news/2017/05/24/white-house-budget-includes-tens-billions-cuts-studentaid-and-research

Laanan, F. S., and Starobin, S. S. (2004). "Defining asian american and pacific islander-serving institutions," in Serving Minority Populations: New Directions the necessary support through policy and practice in higher education (Teranishi, 2010) that transcends beyond boundaries locally, nationally, and globally. AANAPISIs can pave pathways in uncovering how higher education institutions reproduce and reduce inequity for low-income APIA college students, who remain to be misunderstood, misrepresented, and misinterpreted in educational research and the institutions that serve them (Teranishi, 2011). During the era of Trump, APIAs are at a juncture to either remain content or regain traction in resisting White supremacist ideologies and practices. We are hopeful that our community chooses the latter in order to control our narratives within political, social, and economic institutions, reclaim our panethnic identity while embracing subethnic differences, and leverage our agency and voice. AANAPISIs federally being designated as part of the MSI community is reified proof that APIA students deserve space, support, and attention in higher education. These institutions have yet to be realized in order for varying forms of activism from students to be actualized.

\section{AUTHOR CONTRIBUTIONS}

RG and AL contributed to the conceptual analysis of this article. Both authors contributed to the writing, revision, and approval of this submission. for Community Colleges, ed B. V. Laden (Hoboken, NJ: Wiley Periodicals), $49-59$.

Lee, E. (2015). The Making of Asian America: A History. New York, NY: Simon and Schuster Paperbacks.

Lee, T. (2017). 10 Resign from President's Advisory Commission on Asian Americans and Pacific Islanders. NBC News. Available online at https://www.nbcnews. com/news/asian-america/10-resign-president-s-advisory-commission-asianamericans-pacific-islanders-n721386

Lefebvre, H. (1991). The Production of Space. Malden, MA: Blackwell Publishing. López, G., Ruin, N. G., and Patten, E. (2017). Key Facts about Asian Americans, A Diverse and Growing Population. Available online at http://www.pewresearch. org/fact-tank/2017/09/08/key-facts-about-asian-americans

Manzano, L. J., Poon, O. A., and Na, V. S. (2017). "Asian American student engagement in student leadership and activism," in Bridging Research and Practice to Support Asian American Students: New Directions for Student Services, eds D. C. Maramba and C. M. Kodama (San Francisco, CA: JosseyBass), 65-79.

Museus, S. D. (2009). "A critical analysis of the invisibility of Southeast Asian American students in higher education research and discourse," in Asian voices: Engaging, Empowering, and Enabling, ed L. Zhan (New York, NY: NLN Press), 59-76.

Museus, S. D. (2014). Asian American Students in Higher Education. New York, NY: Routledge.

Museus, S. D., Antonio, A. L., and Kiang, P. N. (2012). The State of Scholarship on Asian American and Pacific Islanders in Education: Anti-Essentialism, Inequality, Context, and Relevance. Honolulu, HI: Asian American and Pacific Islander Research Coalition.

Museus, S. D., and Kiang, P. N. (2009). "The model minority myth and how it contributes to the invisible minority reality in higher education research," in Conducting Research on Asian Americans in Higher Education: New Directions for Institutional Research, ed S. D. Museus (San Francisco, CA: Jossey-Bass), 5-15.

Museus, S. D., Maramba, D. C., and Teranishi, R. T. (2013). The Misrepresented Minority: New Insights on Asian Americans and Pacific Islanders, and the Implications for Higher Education. Sterling, VA: Stylus Publishing. 
Museus, S. D., and Park, J. J. (2015). The continuing significance of racism in the lives of Asian American college students. J. Coll. Stud. Dev. 56, 551-569. doi: $10.1353 /$ csd.2015.0059

National Commission on Asian American and Pacific Islander Research in Education (CARE) (2011). The Relevance of Asian Americans \& Pacific Islanders in the College Completion Agenda. New York, NY.

National Commission on Asian American and Pacific Islander Research in Education (CARE) (2012). Asian American And Native American Pacific Islander-Serving institutions: Areas of Growth, Innovation, and Collaboration. New York, NY.

National Commission on Asian American and Pacific Islander Research in Education (CARE) (2013). Partnership for Equity in Education Through Research (PEER): Findings from the First Year of Research on AANAPISIs. New York, NY.

National Commission on Asian American and Pacific Islander Research in Education (CARE) (2014). The Impact of Scholarships for Asian American and Pacific Islander Community College Students: Findings from an Experimental Design Study. New York, NY.

National Commission on Asian American and Pacific Islander Research in Education (CARE) (2015). Measuring the Impact of MSI Funded Programs on Student Success: Findings from the Evaluation of Asian American and Native American Pacific Islander-Serving Institutions. New York, NY.

Nguyen, B. M. D., Nguyen, M. H., Chan, J., and Teranishi, R. T. (2016). The Racialized Experiences of Asian American and Pacific Islanders: An Examination of Campus Racial Climate at the University of California, Los Angeles. Los Angeles, CA: National Commission on Asian American and Pacific Islander Research in Education.

Nguyen, B. M. D., Nguyen, M. H., and Nguyen, T. L. K. (2014). Advancing the Asian American and Pacific Islander data quality campaign: data disaggregation practice and policy. Asian Am. Policy Rev. 24, 55-67. Available online at: http:// aapr.hkspublications.org/2014/06/04/advancing-the-asian-american-andpacific-islander-data-quality-campaign-data-disaggregation-practice-andpolicy

Nguyen, T. H., and Gasman, M. (2015). Activism, identity and service: the influence of the Asian American movement on the educational experiences of college students. History Educ. 44, 339-354. doi: 10.1080/0046760X.2014.1003338

Nguyen, T. H., Nguyen, B. M. D., Nguyen, M. H., Gasman, M., and Conrad, C. (2018). From marginalized to validated: an in-depth case study of an Asian American, Native American and Pacific Islander serving institution. Rev. Higher Educ. 41, 327-363. doi: 10.1353/rhe.2018.0011

Omi, M., and Winant, H. (2015). Racial Formations in the United States, 3rd Edn. New York, NY: Routledge.

Osajima, K. (1995). Racial politics and the invisibility of Asian Americans in higher education. Educ. Foundat. 9, 35-53. Available online at: https:// www.researchgate.net/publication/234595684_Racial_Politics_and_the_ Invisibility_of_Asian_Americans_in_Higher_Education

Osajima, K. (2007). Replenishing the ranks: raising critical consciousness among Asian Americans. J. Asian Am. Stud. 10, 59-83. doi: 10.1353/jaas.2007.0006

Park, J. J., and Chang, M. J. (2010). Asian American Pacific Islander serving institutions: the motivations and challenges behind seeking a federal designation. AAPI Nexus Policy Pract. Commun. 7, 107-125. Available online at: https://files.eric.ed.gov/fulltext/ED518853.pdf

Park, J. J., Lin, M. H., Poon, O. A., and Chang, M. J. (2008). "Asian American college students and civic engagement," in The State of Asian America: The Trajectory of Civic and Political Engagement, ed P. Ong (Los Angeles, CA: LEAP Asian Pacific American Public Policy Institute), 75-98.

Park, J. J., and Teranishi, R. T. (2008). “Asian American and Pacific islander serving institutions: historical perspectives and future prospects," in Interdisciplinary
Approaches to Understanding Minority Serving Institutions, eds M. Gasman, B. Baez, and C.S. Turner (Albany, NY: SUNY Press), 111-126.

Ryoo, J. J., and Ho, R. (2013). "Living the legacy of '68: The perspectives and experiences of Asian American student activists," in The Misrepresented Minority: New Insights on Asian Americans and Pacific Islanders, and the Implications for Higher Education, eds S. D. Museus, D. C. Maramba, and R. T. Teranishi (Sterling, VA: Stylus Publishing), 213-226.

Suzuki, B. H. (2002). "Revisiting the model minority stereotype: Implications for student affairs practice and higher education," in Working with Asian American College Students: New Directions for Student Services, eds M. K. McEwen, C. M. Kodama, A. N. Alvarez, S. Lee, and C. T. H. Liang (San Francisco, CA: Jossey-Bass), 21-32.

Takagi, D. (1992). The Retreat from Race: Asian-American Admissions and Racial Politics. New Brunswick, NJ: Rutgers University Press.

Teranishi, R.T. (2007). "Asian American and Pacific Islander activism," in Encyclopedia of Activism and Social Justice, eds G. Anderson and K. Herr (Thousand Oaks, CA: Sage), 198-199.

Teranishi, R. T. (2010). Asians in the Ivory Tower: Dilemmas of Racial Inequality in American Higher Education. New York, NY: Teachers College Press.

Teranishi, R. T. (2011). Asian American and Native American Pacific Islander-Serving Institutions: Areas of growth, innovation, and collaboration. AAPI Nexus Asian Am. Pac. Island Policy Pract. Commun. 9, 151-155. doi: 10.17953/appc.9.1-2.1313pw1214t2w672

Teranishi, R. T., Alcantar, C. M., and Underwood, R. A. (2018). “AANAPISI leadership: perspectives from the field," in Effective Leadership at MinorityServing Institutions, eds R. Palmer, D. Maramba, A. Arroyo, T. Allen, T. Fountaine Boykin, and J. Lee (New York, NY: Routledge), 186-198.

Teranishi, R. T., Maramba, D. C., and Ta, M-H. (2012). “Asian American Native American Pacific Islander Serving-Institutions (AANAPISIs): mutable sites of intervention for STEM opportunities and outcomes," in Fostering Success of Ethnic and Racial Minorities in STEM: The Role of Minority Serving Institutions, eds R. Palmer, D. C. Maramba, and M. Gasman (New York, NY: Routledge), $168-180$.

Umemoto, K. (1989). “On strike!” San Francisco State College strike, 1968-69: the role of Asian American students. Amerasia J. 15, 3-41. doi: 10.17953/amer.15.1.7213030j5644rx25

Wei, M., Yeh, C. J., Chao, R. C. L., Carrera, S., and Su, J. C. (2013). Family support, self-esteem, and perceived racial discrimination among Asian American male college students. J. Couns. Psychol. 60, 453-461. doi: 10.1037/a0032344

Wei, W. (1993). The Asian American Movement. Philadelphia, PA: Temple University Press.

Wray-Lake, L., Tang, J., and Victorino, C. (2017). Are they political? Examining Asian American college students' civic engagement. Asian Am. J. Psychol. 8, 31-42. doi: 10.1037/aap0000061

Wu, F. H. (2002). Yellow: Race in America beyond Black and White. New York, NY: Basic Books.

Conflict of Interest Statement: The authors declare that the research was conducted in the absence of any commercial or financial relationships that could be construed as a potential conflict of interest.

The reviewer AM and handling Editor declared their shared affiliation at time of review.

Copyright (c) 2018 Gutierrez and Le. This is an open-access article distributed under the terms of the Creative Commons Attribution License (CC BY). The use, distribution or reproduction in other forums is permitted, provided the original author(s) and the copyright owner(s) are credited and that the original publication in this journal is cited, in accordance with accepted academic practice. No use, distribution or reproduction is permitted which does not comply with these terms. 